\title{
鋼製杭の浅層土塨中における暴露試験
}

\author{
藤橋健太 ${ }^{1)}$ *, 奥地 誠 ${ }^{1)}$, 押川 渡 ${ }^{2}$, 田原 晃 ${ }^{3)}$, \\ 篠原 正 $^{4)}$, 片山英樹 ${ }^{4)}$ \\ 1) 奥地建産株式会社 \\ 2) 琉球大学 工学部 工学科 エネルギー環境工学コース \\ 3) 公益社団法人腐食防食学会 \\ 4) 物質・材料研究機構 構造材料研究拠点 腐食特性グループ
}

\section{Exposure Corrosion Test of Metal Pile for Shallow Soil Layer}

\author{
Kenta Fujihashi ${ }^{1{ }^{*}}$, Makoto Okuji ${ }^{1)}$, Wataru Oshikawa ${ }^{2)}$, Akira Tahara ${ }^{3)}$, \\ Tadashi Shinohara ${ }^{4)}$ and Hideki Katayama ${ }^{4)}$ \\ 1) Okuji-Kensan Corporation \\ 2) Energy and Environment Program, School of Engineering, Faculty of Engineering, University of the Ryukyus \\ 3) Japan Society of Corrosion Engineering \\ 4) Corrosion property group, Research Center for Structural Materials, National Institute for Materials Science
}

\author{
*責任著者(Corresponding Author)＝541-0054 大阪市中央区南本町 4-1-8(4-1-8 Minamihommachi, Chuo-ku, Osaka, 541-0054, Japan) \\ E-mail: k_fujihashi@okuji.co.jp
}

\begin{abstract}
The number of photovoltaic system has increased drastically due mainly to a profitable selling price of electricity for owners set by feed-in tariff. Metal piles are currently used as typical foundation of the system from the viewpoint of high workability and low cost. However, there is a problem that the corrosion rate of metal foundation pile at ground level is faster than that of other part of the pile. In this paper, soil corrosion at shallow layer was investigated by exposure test in soil, chemical analysis of soil and electrochemical analysis. The corrosion rate of metal pile in shallow soil layer was higher than $0.02 \mathrm{~mm}$ /year which is commonly recognized as the corrosion rate of metal in soil. The corrosion rate in shallow soil layer mostly increased with decreasing the polarization resistance measured in soil environment. Those investigated results showed that the macro cell corrosion at ground level is thought to be attributed to change of chemical composition caused by land creation and dispersion of manure.
\end{abstract}

Key words : soil corrosion, macro cell corrosion, ground level, exposure test, passivity film, AC impedance method

\section{1. 緒}

\section{$\overline{\overline{⿳ 亠 二 口}}$}

我が国では再生可能エネルギー固定買取制度を背景に 太陽光発電設備が急増した。 太陽光発電設備の基礎構造 は，かつて鉄筋コンクリートによる直接基礎が主流であっ たが，より安価で施工性の高い鋼製杭基礎へと変化して きた。ここで用いられる鋼製杭は，かねてより建築や土 木分野で用いられている鋼製杭とは大きく異なる。建築 や土木分野で用いられる鋼製杭は，フーチングなどの鉄 筋コンクリートの基礎を支える目的で土猿中に完全に埋 設されており，杭表面が大気にさらされることは少な い.そのため，鋼製杭の腐食速度は土壌によらず年間 $0.02 \mathrm{~mm}$ と言われる ${ }^{1)}$.

それに対し, 太陽光発電設備における鋼製杭は, 地盤 に直接打ち込む工法が一般的に採用されており，杭上部 が大気中に突出している。 また地際部，浅層土壌中にお いては，雨水の滞留などが見られる。そのため土壤の通 気性, 地下水による酸素濃淡電池の形成や, 土壌中の腐 食 $^{2)-4)}$ において確認されている微生物などによる局所的

第 64 回材料と環境討論会(那覇, 2017 年)で発表
に大きな腐食 ${ }^{5)}$ の発生が懸念される.

しかし，浅層土壌中に金属表面が接し，地際部より突 出しているこのような環境における腐食の知見は少な く, デー夕の蓄積, 解析が必要である. そのため, 地際 部から浅層土壤中にかけての腐食量を測定することを目 的に 2016 年 5 月より, 全国 3 箇所で杭状サンプルの暴 露試験を開始した，本報では，暴露 1 年目の結果を報告 し, 各暴露試験場の浅層土壤を回収, 分析することで腐 食要因の検討を行った。

\section{2. 実 験 方 法}

\section{1 暴露試験場}

本暴露試験は三重県伊賀市 (以下伊賀，Iga)，奈良県 葛城市 (以下葛城, Katsuragi), 沖縄県西原町 (以下西 原, Nishihara)の 3 箇所で実施した。これらの暴露試験 場は飛来海塩粒子量が土壌中腐食へ与える影響と地下水 位の影響を検証することを考慮して選定した，暴露期間 における飛来海塩粒子量は, 伊賀が $0.02 \mathrm{mg} / \mathrm{dm}^{2} / \mathrm{day}$, 西原が $0.17 \mathrm{mg} / \mathrm{dm}^{2} /$ day となり，大きな差があるため, 飛来海塩粒子量が土㙵中腐食へ与える影響を検証するこ とを目的に選定した。 また，葛城については，地下水位 
が高く，周辺に水田が広がっているため，土壤はほぼ湿 潤状態である，港湾施設における鋼製杭，鋼矢板の腐食 は，干潮時水位の直下がアノードとなりマクロセル腐食 が発生することが示されている ${ }^{6)}$ ため, 土壌中でもマク ロセル腐食の発生を考慮し, 選定した。

\section{2 暴露試験体}

土壤の通気性の違いや土㙵層の変化により, 深さ方向 で腐食の傾向が異なることが予想されたため, Fig. 1(a) のような試験杭を作製し，深さ方向 $50 \mathrm{~mm}$ ごとに腐食 減量を測定した。試験杭は全長 $1,800 \mathrm{~mm}, \phi 35 \mathrm{~mm}$ であ り，腐食減量を測定するための円筒形試験片 (Fig. 1(b)) を 30 体取り付けた，腐食減量の測定範囲は $1,500 \mathrm{~mm}$ で ある. 試験杭と円筒形試験片の材質は炭素鋼 $(\mathrm{S} 45 \mathrm{C})$ と し, そのミルシートの抜粋とサイズを Table 1 に示した. また，円筒形試験片の内面と上下面には低温黒色クロム めっきを施し，主に外表面が腐食するようにした．試験 杭に取り付けられた円筒形試験片は全て電気的にショー トさせ，マクロセル腐食による減量も測定できるように した.

この試験杭を 2016 年 5 月に各暴露試験場に打ち込み, 約 1 年間暴露した。伊賀, 暮城については, 腐食減量の 測定範囲が大気中に約 $300 \mathrm{~mm}$, 土堙中に約 $1,200 \mathrm{~mm}$ となるように打ち込んだ。西原については, 腐食減量の 測定範囲が大気中に約 $600 \mathrm{~mm}$, 土壤中に約 $900 \mathrm{~mm}$ と なるように打ち込んだ。

\section{3 腐食減量測定}

円筒形試験片の除錆処理は，インヒビターを添加した
塩酸除錆液に全体を浸漬させて行った。しかし，この除 錆液では, 内面の低温黒色クロムめっきも溶解するた め，あらかじめ円筒形試験片のブランク材 3 体を同様の 除錆液に浸漬し，処理を行って算出した平均めっき質量 を考慮して腐食減量を算出した。

\section{4 土壤回収}

腐食の要因を考察する目的で, 各暴露試験場から層ごと に土壤を 2017 年 7 月に回収した。表層 $20 \mathrm{~mm}$ から $50 \mathrm{~mm}$ 程度を除き，そこから深度 $50 \mathrm{~mm}$ ごとに $1,000 \mathrm{~mm}$ 四方 の穴から回収した。伊賀，西原については，深度 $500 \mathrm{~mm}$ まで回収したが，葛城のみ深度 $280 \mathrm{~mm}$ 程度から水が湧 き上がり，回収が困難となった。その場で外観により分 類すると Fig. 2 のようになった．伊賀は深度約 $500 \mathrm{~mm}$ までの範囲で，三つの層があり，全ての層で砂利を多く 含んでいた，葛城は深度約 $300 \mathrm{~mm}$ までの範囲で，四つ の層があり，非常に薄い層が多かった。もとの水田と思 われる土は 3 層目からであり, 4 層目では水が湧き出し, 掘り進むことが困難となった。西原は深度約 $500 \mathrm{~mm}$ ま での範囲で, 均一な単層であった。

\section{5 土壊の成分分析}

外観により分類した層ごとに土䁃の成分分析を行った. 西原の土䁃のみ単層であったが，深度 $0 \mathrm{~mm}$ から $50 \mathrm{~mm}$ の土壤と $250 \mathrm{~mm}$ から $300 \mathrm{~mm}$ の土壤の 2 種を分析した ため合計 9 土壤を分析対象とした。

分析は細粒分測定, 蛍光 X 線分析 (リガク社製 ZSX Primus II )による半定量分析, 土壤抽出液の $\mathrm{pH}$ 測定 (HORIBA 製 F-21)，イオンクロマトグラフ法によるイオ (a)

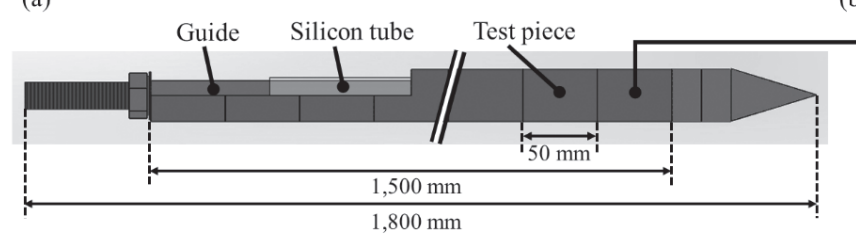

(b)

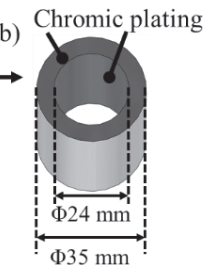

Fig. 1 Schematic drawings of (a) pile and (b) test piece for exposure test

Table 1 Chemical composition and size of exposure test piece

\begin{tabular}{|c|c|c|c|c|c|c|c|c|}
\hline \multicolumn{6}{|c|}{ Chemical composition [mass\%] } & \multicolumn{4}{c|}{ Size } \\
\hline $\mathrm{C}$ & $\mathrm{Si}$ & $\mathrm{Mn}$ & $\mathrm{P}$ & $\mathrm{S}$ & $\mathrm{Fe}$ & Outside diameter [mm] & Inside diameter [mm] & Height [mm] \\
\hline 0.46 & 0.21 & 0.65 & 0.008 & 0.018 & bal. & 35 & 24 & 50 \\
\hline
\end{tabular}

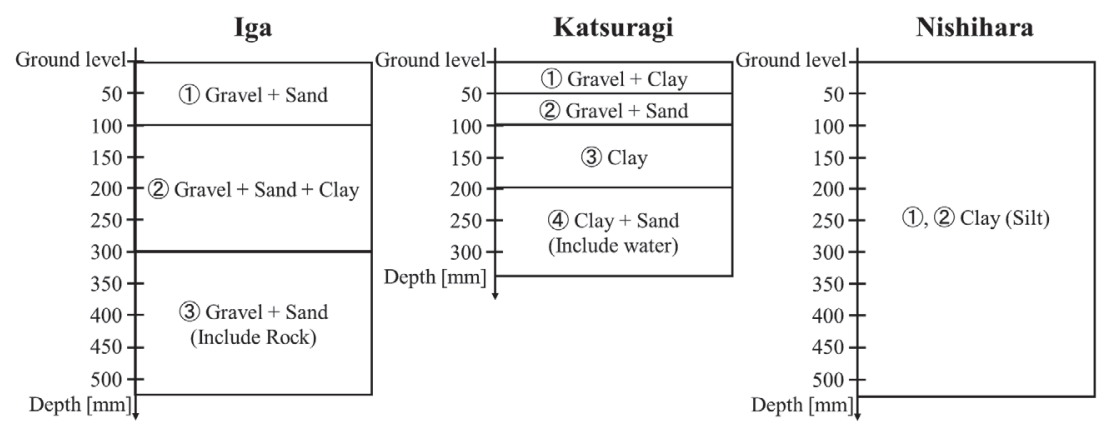

Fig. 2 Soil type at each depth of shallow layer at Iga, Katsuragi and Nishihara test sites 
ン濃度分析 (DIONEX 製 ICS-1100)を行った。細粒分は目 開き $75 \mu \mathrm{m}$ のメッシュを通った土壌の重量割合を示し, 土袞抽出液は, それぞれの土潩 $75 \mathrm{~g}$ を量り取り, 超純 水 $150 \mathrm{ml}$ を加え, 20 分振とう後，ろ紙でろ過して作製 した。

\section{6 土壤を電解質とした交流インピーダンス測定 2.6 .1 測定セルの作製}

各暴露試験場で回収した土䁃を $110^{\circ} \mathrm{C}$ の定温乾燥器 (ア ズワン社製 $\mathrm{EO}-450 \mathrm{~B})$ 内で完全乾燥させ，ミル(ラボネク 卜社製 HS-20)で粉砕後, 目開き $1 \mathrm{~mm}$ のメッシュに通し た.メッシュを通過した土塞に，その重量に対して $15 \mathrm{wt} \%$ の純水を添加し，よく攪拌することで試験土壤とした。 この純水の添加量については，事前に行った予備実験に おいて, 細粒分が異なると土壤の保水性が大きく異な り，電気化学測定ができない場合があることが判明し た。そのため細粒分が大きく異なっていても測定が可能 であった $15 \mathrm{wt} \%$ とした。

$\mathrm{ANSI}^{7)}$ で示される土壤の腐食性を抵抗值によって評価 する方法を参考に Fig. 3 で示すアクリル製の測定セル ボックスを作製した。このセルボックスの底となる炭素 鋼 $(\mathrm{SPCC})$ 電極と電極の切欠から参照電極用の塩橋を取 り付け, 試験土㙥を 4 回から 5 回に分けて入れた。試験 土壤を 1 回入れるごとに自作ランマー(重量 : $1,439 \mathrm{~g}$, 先端： $\phi 20 \mathrm{~mm}$ )で締固めた。 そして蓋となる白金電極を上 に置き，ボルトで電極を土壌に圧着して測定セルとした。

2.6 .2 交流インピーダンス測定

2.6 .1 で作製した測定セルを 3 電極法による交流インピー

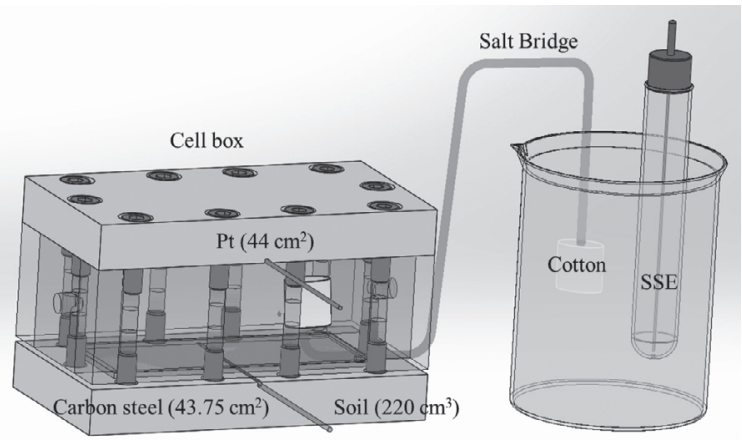

Fig. 3 Schematic drawing of measuring equipment

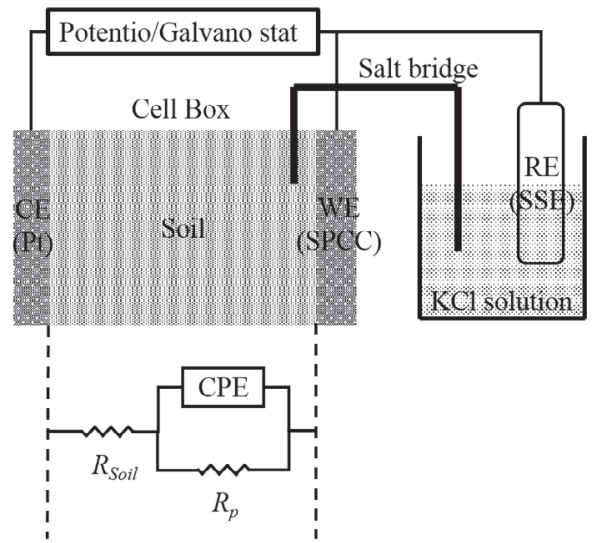

Fig. 4 Equivalent circuit of measuring equipment
ダンス測定を行った．本実験における測定セルの等価回 路と模式図を Fig. 4 に示す。測定は $25^{\circ} \mathrm{C}$ ，95\% RH の恒 温恒湿槽 (ESPEC 製 LHL-114) 内に 30 分静置した後に, 交流インピーダンス測定を行った。測定装置はポテンショ スタット (東方技研製 PS-08) と周波数特性分析器 (NF 回 路設計ブロック製 FRA5022)を用い，測定周波数範囲は $100 \mathrm{kHz}$ から $1 \mathrm{mHz}$ ，交流振幅を $10 \mathrm{mV}$ で測定を行っ た.これらの結果から土㙵抵抗 $\left(\mathrm{R}_{\mathrm{soil}}\right)$, 分極抵抗 $\left(\mathrm{R}_{\mathrm{p}}\right)$ を 決定し，土袞の腐食性を評価した。

\section{3. 結果および考察}

\section{1 各深度の腐食減量測定結果}

各暴露試験場における各深度の腐食減量測定結果を Fig. 5 に示す。土㙵中における腐食は年間 $0.02 \mathrm{~mm}$ と言 われるが，全体的に上回っているプロットが多く，伊賀 の浅層土㙴中では最大で年間 $0.04 \mathrm{~mm}$ 程度の腐食をする ことが分かった。

伊賀と西原を比較すると，大気中における腐食減量は 西原のほうが大きいが，土壤中では伊賀のほうが大きく なった。浅層土壤中では飛来海塩粒子が堆積し, 濃度が 高まり, 特に地際部で腐食が大きく進行することが予想 されたが，この結果から土壤腐食に対する大気の影響は 小さいと考えられる.

Fig. 6 に葛城における暴露した試験杭の腐食外観と円 筒形試験片の代表的な腐食外観を示す。この円筒形試験 片の内面と上下面には低温黒色クロムめっきを施した が, 土壤中の円筒形試験片の外表面 (Fig. 6(b), (c), (d)) は一様に腐食している。このことから低温黒色クロムめっ きと土壤は接触しておらず，低温黒色クロムめっきは，円 筒形試験片の外表面の腐食に影響していないと判断した。

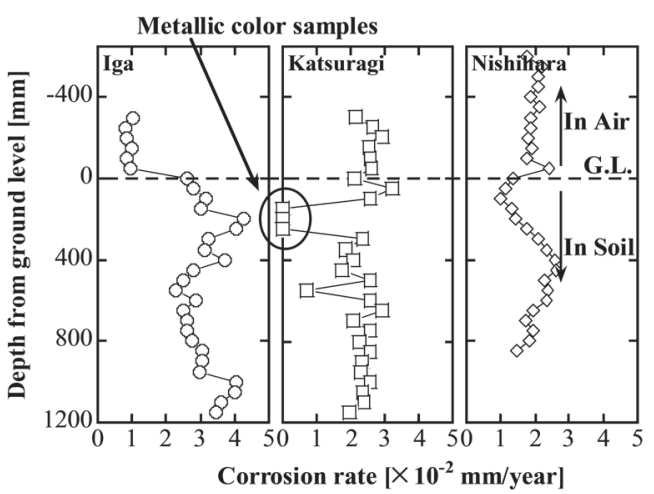

Fig. 5 Relationship between corrosion rate and depth from ground level at each site

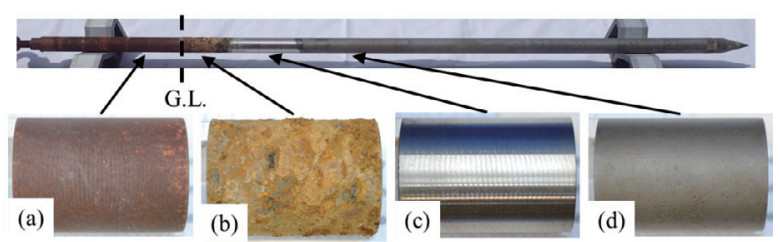

Fig. 6 Appearance of test pile and test pieces exposed for one year at Katsuragi in (a) air, (b) soil (Shallow layer), (c) soil (Middle layer) and (d) soil (Deep layer) 
地際部直下 (Fig. 6(b))では, 腐食減量は暮城において 最も大きい值を示し, 外観も腐食による減耗が, その他 の深度と比較して大きいように見える。 そして, 減耗の 大きい領域のすぐ下，深度 $125 \mathrm{~mm}$ から $250 \mathrm{~mm}$ では金 属色を示し，点錆も見られない Fig. 6(c))。このことか ら, 地下水位が高く, 土㙵もほぼ湿潤状態にあるような 土壌環境では, 地際部直下をアノード, 金属色を示した 部分をカソードとしたマクロセル腐食の発生が考えられ る。これは，海洋環境での鋼の腐食における干潮時水位 の直下の腐食極大 ${ }^{6)}$ と類似しているが，点錆もない金属 色を残すことについては説明できなかった.

\section{2 土壊の成分分析結果}

そこで各暴露試験場から回収した 9 試験土壤 (Fig. 2 参 照)の成分分析を行った。土壤の細粒分と蛍光 X 線分析 結果の抜粋を Table 2 に, 抽出液の $\mathrm{pH}$, イオン濃度の結 果を Table 3 に示す.

西原の 1 層目, 2 層目共にナトリウムイオン, 塩化物 イオンが比較的高い值を示し, 3.1 各深度の腐食減量測 定結果では大気の影響は小さいと述べたが, 土壤中に海 塩粒子が堆積していることが分かった。このことから土 猿腐食は, 本報のような 1 年間の短期間の暴露試験結果 には海塩粒子の影響がないと考えられる。しかし, より 長期の暴露試験結果には海塩粒子の影響が反映される可 能性がある。

また，葛城の 3 層目と伊賀の 3 層目は，抽出液の $\mathrm{pH}$ が非常に高かった，暮城の 3 層目については，暴露試験 において金属色を示した層と深度がほぼ一致しており, この高 $\mathrm{pH}$ が鋼材表面を不働態化したと考えられる。ま た，この部分だけ電位が貴化したことで，カソードとな り，より防食されたと考えられる。

Table 2 Results of ratio of fine particle and chemical analysis of soil at each depth at Iga, Katsuragi and Nishihara test sites

\begin{tabular}{|c|c|c|c|c|c|c|c|c|c|c|c|}
\hline \multirow{2}{*}{\multicolumn{2}{|c|}{ Sample number }} & \multirow{3}{*}{ 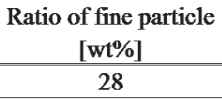 } & \multicolumn{9}{|c|}{ Major element [wl\%] } \\
\hline & & & \multirow{2}{*}{\begin{tabular}{|c|} 
C \\
3.3
\end{tabular}} & \multirow{2}{*}{$\begin{array}{c}\mathrm{O} \\
54\end{array}$} & \multirow{2}{*}{$\frac{\mathrm{Mg}}{0.6}$} & \multirow{2}{*}{$\begin{array}{r}\text { A1 } \\
9.9\end{array}$} & \multirow{2}{*}{$\begin{array}{l}\mathrm{Si} \\
24\end{array}$} & \multirow{2}{*}{$\begin{array}{c}\mathrm{P} \\
0.07\end{array}$} & \multirow{2}{*}{\begin{tabular}{|c|} 
S \\
0.04
\end{tabular}} & \multirow{2}{*}{$\frac{K}{2.0}$} & \multirow{2}{*}{$\begin{array}{l}\mathrm{Ca} \\
1.5 \\
\end{array}$} \\
\hline \multirow{3}{*}{ Iga } & (1) & & & & & & & & & & \\
\hline & (2) & 30 & 2.6 & 53 & 0.9 & 8.9 & 26 & 0.06 & 0.03 & 2.6 & 1.1 \\
\hline & (3) & 10 & 2.1 & 50 & 1.0 & 7.5 & 26 & 0.05 & 0.27 & 2.2 & 5.2 \\
\hline \multirow{4}{*}{ Katsuragi } & (1) & 25 & 3.4 & 53 & 1.4 & 8.5 & 24 & 0.14 & 0.05 & 1.4 & 2.6 \\
\hline & (2) & 12 & 2.0 & 53 & 1.1 & 7.4 & 25 & 0.07 & 0.02 & 1.7 & 4.4 \\
\hline & (3) & 25 & 4.3 & 53 & 1.3 & 8.1 & 22 & 0.16 & 0.07 & 1.3 & 5.0 \\
\hline & (4) & 20 & 3.1 & 53 & 1.3 & 8.7 & 24 & 0.16 & 0.06 & 1.3 & 2.3 \\
\hline \multirow{2}{*}{ Nishihara } & (1) & 84 & 4.2 & 52 & 1.2 & 9.0 & 22 & 0.07 & 0.06 & 2.2 & 3.0 \\
\hline & (2) & 87 & 4.1 & 52 & 1.2 & 8.7 & 21 & 0.06 & 0.05 & 1.7 & 4.4 \\
\hline
\end{tabular}

Table 3 Results of $\mathrm{pH}$ and ion of soil at each depth at Iga, Katsuragi and Nishihara test sites

\begin{tabular}{|c|c|c|c|c|c|c|c|c|c|c|}
\hline \multirow{2}{*}{\multicolumn{2}{|c|}{ Sample number }} & \multirow{3}{*}{$\frac{\mathrm{pH}(\mathrm{C})}{5.26(26.4)}$} & \multicolumn{8}{|c|}{ Amounts of ion [mg/100g soil] } \\
\hline & & & \multirow{2}{*}{$\begin{array}{l}\mathrm{Cl}^{-} \\
0.2\end{array}$} & \multirow{2}{*}{\begin{tabular}{|c|}
$\mathrm{SO}_{4}{ }^{2-}$ \\
0.89 \\
\end{tabular}} & \multirow{2}{*}{$\frac{\mathrm{Na}^{+}}{0.92}$} & \multirow{2}{*}{$\frac{F^{-}}{<0.03}$} & \multirow{2}{*}{$\frac{\mathrm{NO}_{2}^{-}}{<0.03}$} & \multirow{2}{*}{$\frac{\mathrm{NO}_{3}^{-}}{18}$} & \multirow{2}{*}{$\frac{\mathrm{K}^{+}}{0.58}$} & \multirow{2}{*}{$\frac{\mathrm{NH}_{4}^{+}}{0.05}$} \\
\hline \multirow{3}{*}{ Iga } & (1) & & & & & & & & & \\
\hline & (2) & $7.00(26.7)$ & 0.14 & 1.9 & 0.32 & 0.04 & $<0.03$ & 1.5 & 0.51 & $<0.03$ \\
\hline & (3) & $11.42(26.5)$ & 0.29 & 13 & 1 & $<0.03$ & 0.04 & 0. & 1.2 & $<0.03$ \\
\hline \multirow{4}{*}{ Katsuragi } & (1) & & 6 & 3.2 & 1.3 & & & & 0.22 & $<0.03$ \\
\hline & (2) & 8.29 & 0.13 & 1 & & & & & 0.13 & $<0.03$ \\
\hline & (3) & $11.80(26.2)$ & 2.3 & 3.4 & 0.16 & 0.21 & $<0.15$ & $<0.15$ & $<0.15$ & 1.6 \\
\hline & (4) & $7.77(26.3)$ & 0.67 & 16 & 0.67 & 0.14 & $<0.03$ & 27 & 0.85 & $<0.03$ \\
\hline \multirow{2}{*}{ Nishihara } & (1) & $7.98(26.2)$ & 2.2 & 3.3 & 1.7 & 0.07 & 0.09 & 3.8 & 0.57 & 0.05 \\
\hline & (2) & $8.01(26.2)$ & 1.2 & 11 & 2.5 & 0.12 & $<0.03$ & 0.26 & 0.15 & $<0.03$ \\
\hline
\end{tabular}

この高 $\mathrm{pH}$ は, 葛城の 3 層目ではアンモニウムイオン 濃度が高く, 伊賀の 3 層目ではカリウムイオン, 硫酸イ オンの濃度が高いことから, 周辺環境から化学肥料の影 響を大きく受けたものであると考えられる。また，カル シウム元素の割合も比較的高いことから，土地造成の際 に重機などの走破性を確保する目的で, 石灰を含む添加 剤を入れ，地盤改良を行った可能性がある。このことか ら, 土壤の $\mathrm{pH}$ については, 人為的な影響が大きく, マ クロセル形成に寄与する可能性があることが分かった.

\section{3 土壤中交流インピーダンス測定結果}

分析を行った土䁃の腐食性評価を分極抵抗測定によっ て行った。本実験のナイキスト線図は，Fig. 4 に示した 等価回路から一つの円弧が得られると考えられる。この 円弧の X 軸との二つの交点において, 低インピーダンス 側を土壤抵抗 $\left(\mathrm{R}_{\text {soil }}\right)$, 高インピーダンス側を土壤抵抗と 分極抵抗 $\left(\mathrm{R}_{\mathrm{p}}\right)$ を足し合わせた值であるとした。一例とし て葛城で回収した土壌を評価した結果をナイキスト線図 で Fig. 7 に示す. Fig. 7 から四つ全ての土壌で円弧が一 つ得られた。伊賀，西原の土壌についての結果でもそれ ぞれの土壌で一つの円弧が得られており，それぞれの分 極抵抗を算出することができた。 そこで暴露試験場ごと に分極抵抗と腐食減量の関係を Fig. 8, Fig. 9, Fig. 10 に 示す. 伊賀 (Fig. 8) については, 分極抵抗が小さい層ほ ど，腐食減量が大きくなる傾向を示した. $\mathrm{pH}$ が高い 3

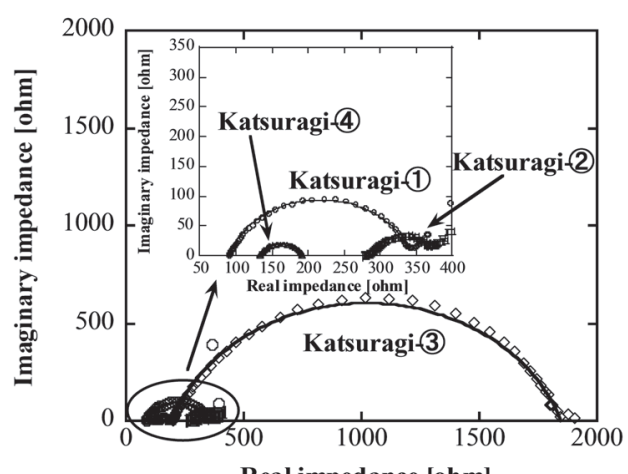

Fig. 7 Nyquist diagrams of carbon steel (SPCC) in soils collected at Katsuragi

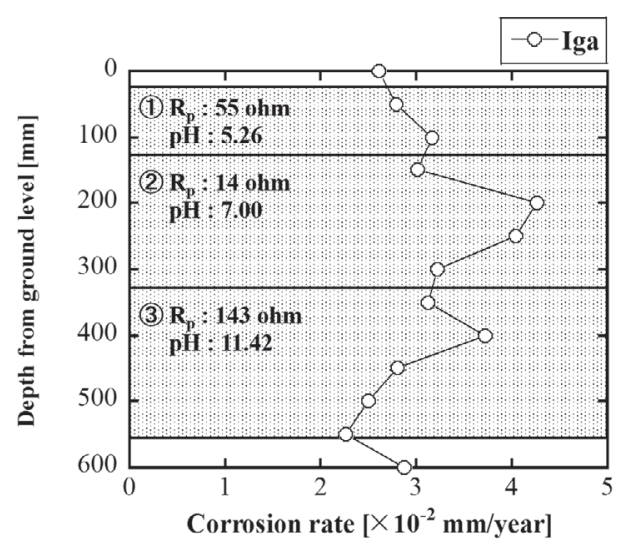

Fig. 8 Relationship between corrosion rate, depth from ground level and polarization resistance at Iga test site 


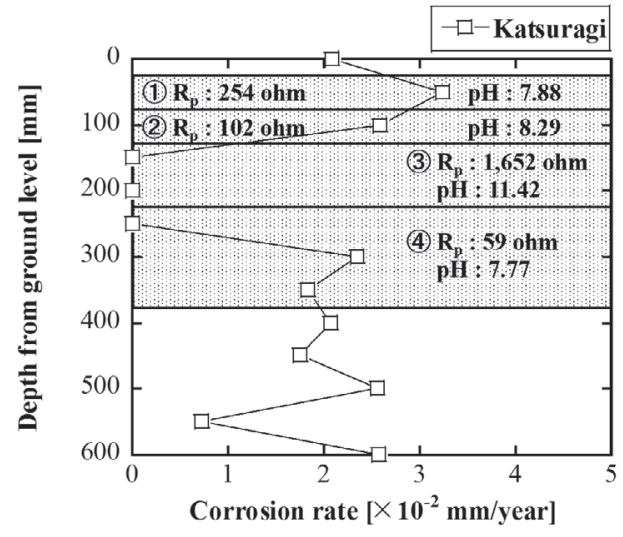

Fig. 9 Relationship between corrosion rate, depth from ground level and polarization resistance at Katsuragi test site

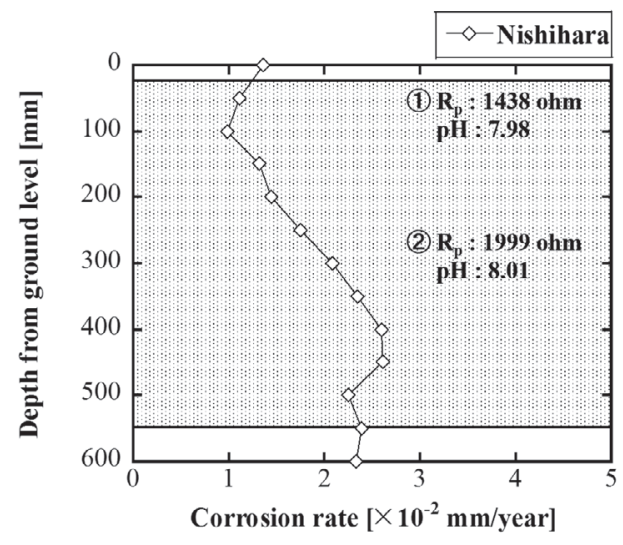

Fig. 10 Relationship between corrosion rate, depth from ground level and polarization resistance at Nishihara test site

層目が最も分極抵抗が高く, 腐食減量も小さかったが, 分極抵抗の上昇幅は小さく，不働態膜が生成していると 考えるには值が小さい. 後述する葛城の 3 層目の分極抵 抗と比較しても一桁程度, 小さい值であるため, 何らか の理由により，不働態膜が生成しづらいことが考えられ るが詳細は不明である。

葛城 (Fig. 9)については，伊賀と同様，分極抵抗と腐 食減量にある程度の相関が見られた. Fig. 7 からも分か るように 3 層目の分極抵抗が非常に大きく，不働態膜の 生成によるものと考えられる。この層にある円筒形腐食 片の腐食減量についても非常に小さい值となっており, 分極抵抗の值と一致する. しかし, 1 層目と 2 層目の分 極抵抗のほうが 4 層目の分極抵抗より大きいにもかかわ らず，腐食減量は大きい值を示した。これは，1層目と 2 層目の部分をアノード, 3 層目をカソードとしてマク ロセル腐食が発生したことで, 1 層目と 2 層目の腐食が 促進されたためと考えられる。

西原 (Fig. 10)については, 1 層目，2 層目で土壤の外 観に違いがなく，成分分析による結果にも大きな違いが 見られなかったこともあり，分極抵抗は非常に大きい值 を共に示し，大きな違いはなかった，しかし，深度が大 きくなるほど, 腐食減量が大きくなっており，伊賀と葛 城で示したような分極抵抗と腐食減量に相関がなかっ た。これは，西原においては Table 2 の細粒分が非常に
大きい值であり，粘土質であったことから，土袞の通気 性が低く, 深度に対する酸素濃度の勾配が大きく, 非常 に浅い層間で酸素濃淡によるマクロセル腐食が発生した ものと考えられる。しかし，土壤の化学組成変化による 腐食量の増減と比較すると, 酸素濃淡による腐食量の増 減は小さかった。

\section{4. 結言}

太陽光発電設備の基礎構造に見られる，浅層土塞中に 金属表面が接し，地際部より金属が突出している環境の 腐食要因を検討するため, 深度毎の腐食減量測定と各暴 露試験場の土壤の成分分析, 土壤を電解質とする電気化 学測定を行った。これにより以下の知見が得られた。

(1)ミクロセル腐食, マクロセル腐食の両方を考慮した 深度ごとの腐食減量測定を行い, 浅層土壌中の腐食 量は, 土畩中の腐食量として一般的に示される年間 $0.02 \mathrm{~mm}$ の腐食量を上回った.

(2) 各土蚺の分極抵抗の測定結果と腐食減量を比較する ことで, 各深度の腐食量は, 各深度の土壌を電解質 として測定された分極抵抗とほぼ相関があることが 分かった。しかし，土壇層の相互作用によるマクロ セル腐食など，土㙵中では他の要因による腐食が発 生することも多く, 腐食量と分極抵抗で相関を示さ ない場合もある.

(3) マクロセル腐食については，化学肥料や土地造成に 用いられる添加剤によって，ある土壌層のみ大幅に 環境が変化することで，その部分の金属表面の電位 が変化し，発生するものと考えられる，土㙵の低い 通気性から起こる酸素濃度勾配によるマクロセル腐 食については, 土畩の化学組成の違いによる影響と 比較して腐食量への寄与は小さいことが分かった.

今後は, 腐食減量測定を測定した試験杭を改造し, 深 度ごとに電極を埋設することで，ガルバニック電流を測 定し，マクロセル腐食の検討を実施していく.

\section{謝辞}

本研究成果は, 国立研究開発法人新エネルギー・産業 技術総合開発機構 (NEDO)の委託業務の結果得られたも のの一部である.

\section{参 考 文 献}

1) Y.Sugimura, K.Noda, M.Toyoshima, K.Sakai, H.Ono, T.Umeno, G.Fukui, F.Chatani, Y.Kikuchi, H.Aoki, M. Tamura, N.Tomonaga, T.Hara, M.Kanda, H.Yokota, T. Mogami, A.Teshigawara, K.Bessho, S.Yamada, A.Yoshida, M.Tanaka, M.Asogawa, T.Shinohara, H.Yamashita, M.Nishiguchi, K.Miyamoto, T.Matsumoto, A.Kimura, A.Abe and A.Suwa, Jibankougaku • jitsumu series 17 Kuikiso no chosa $\cdot$ sekkei $\cdot$ seko kara kensa made, Japanese Geotechnical society, p.236 (2004).

2) M.Kobayashi, S.Kiya, R.Nemoto, K.Horioka, S.Kaneko and Y.Inoue, Boshoku-Gijutsu, (presently Zairyo-to-Kankyo) 38, pp.327-332 (1989).

3) N.Emukai and H.Takazawa, Zairyo-to-Kankyo, 42, pp.136143 (1993).

4) K.Yamamoto, K.Kudou, K.Nishi, Kaiyo Kaihatsu Ronbun shu, 8, pp.201-205 (1992).

5) F.Kajiyama, Zairyo-to-Kankyo, 46, pp.491-497 (1997).

6) K.Matsuoka, M.Yamamoto and K.Goto, Zairyo-to-Kankyo, 56, pp.99-105 (2007). 
要旨

再生可能エネルギー固定買取制度を背景に, 太陽光発電設備は急増した。太陽光発電設備の基礎杭は, 浅層土壤中に金属表面が接し，地際部より突出している，本研究では，この環境における腐食の把握を目

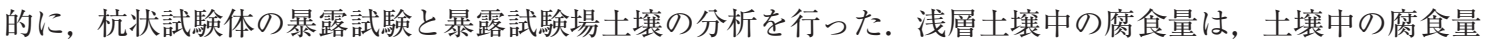
として一般的に示される年間 $0.02 \mathrm{~mm}$ の腐食量を上回った. それらの腐食量は各土潩を電解質とした分極 抵抗測定結果と良い相関を得た。地際部のマクロセル腐食は, 土地造成など人為的な作用により土㙵の化 学組成が大きく変化することが一因であると考えられる.

キーワード土畩腐食, マクロセル腐食, 地際部, 暴露試験, 不働態皮膜, 交流インピーダンス法 